\title{
A Demand And Supply Analysis Of The Confluence Of Student Loan Stakeholder Interests
}

\author{
Loreto Peter Alonzi, Dominican University, USA \\ Robert Irons, Dominican University, USA \\ Khalid A. Razaki, Dominican University, USA
}

\begin{abstract}
This paper addresses the question of why the student loan crisis has arisen through the use of a demand and supply model. The model serves as a framework for analyzing the student-borrower motivations (the demand side), the bank-lender motivations (the supply side), externalities that motivate government support for student loans, and the perverse incentives government regulations spawn for educational institutions and lenders. Analysis of the model reveals that the crisis is driven by students' desire to increase their socioeconomic standing, by banks' search for profits in a climate of decreasing risk, and by the government's efforts to lessen the impact of externalities.
\end{abstract}

Keywords: Student Loan Crisis; Demand And Supply; Bank Lending; Socioeconomic Mobility; Externalities; Government Action

\section{INTRODUCTION}

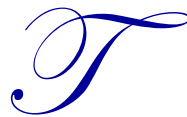

he soaring volume of student loans and their default rates have raised the question, "why has this student loan crisis arisen?" This paper answers the question by using the demand and supply model as the framework for drawing together four separate strands of inquiry found in the literature into one focused analysis.

Subsequent sections of this paper recount the arguments of Razaki et al. (2014) that affect the demand by students for loans; discuss the context of the student loan market, in particular the externalities involved and the resulting government action; draw on the bank-lending literature of Alonzi et al. (1980, 1983, 2010, and 2011) that was developed prior to the student loan crisis and is now being applied to the supply side of the student loan market; draw these strands together in a demand and supply analysis to explain the surge in student loan volume contributing to the student loan crisis; and provide two policy recommendations.

\section{Demand By Students For Loans}

The work by Razaki et al. (2014) reveals a reason for the very strong demand by students and their families for student loans. They point out that for decades people have found that education "provides 'the chance to move a person from one socio-economic level to another to open doors"" that are otherwise closed to them. The acquisition of education can lead to a more prosperous future, but without an education, a person may be relegated forever to a poorer future. The view of Razaki et al. (2014) is supported by a recent Pew Foundation (2014) study. The Pew Foundation reported that persons with a bachelor's degree, on average, earn $\$ 45,500$, have a $3.8 \%$ unemployment rate and a $5.0 \%$ poverty rate, while the corresponding numbers for persons with a two-year degree are $\$ 33,000$, $8.1 \%$ and $14.7 \%$; and for a high school graduate, they are $\$ 28,000,12.82 \%$, and $21.8 \%$, respectively. So the student loan is, as Razaki et al. (2014) put it, the way "to seize the opportunity to have a chance for a better life... from this perspective, the payoff to student loan debt, though uncertain, dwarfs the risk in the minds of parents wishing only a better life for their children." 
From this argument of Razaki et al. (2014), the authors draw the implication that the demand for student loans was very strong due to the dream to move up in socio-economic order.

\section{Government Action In Student Loan Market: Context For Demand And Supply}

\section{Externalities And Government Student Loan Guarantees}

Education, in general, and higher education, in particular, benefit society beyond the benefits accruing privately to the individual receiving the education. Essentially, it can be surmised that, on average, individuals with a college degree bring to their decision-making a greater depth and breadth of exposure to the philosophical verities of life as well as the concepts and skills of the high tech information age. Further, such individuals may better comprehend the complexity of the interrelationships of those philosophical verities as well as the technical concepts and skills and their application than do those with less formal education. Thus, educated individuals, on average, tend to be more able to live an effective life suited not only to the employment needs of the high tech/information age but also to the needs of every day human experience. Complementing these phenomena is the university curricula's focus on critical thinking and problem-solving skills used by those in business, science, government and the law to the benefit of ALL citizens.

The benefits of better decision-making accrue not only to the private individual making the decision but also spill over to the economy as a whole. These external benefits are unlikely to be fully reflected in the salaries that graduates earn. Thus, the markets for these skills miss the benefits external to the private decisions of demanders and suppliers of education. Neglecting these external social benefits leads to a lower quantity of educational services chosen than would be the case if all the external benefits of education had been incorporated in the decision process. Society is denied the benefits of a more educated populace because it undervalues education. Consequently, many with the potential to raise their standard of living are denied the opportunity to drive positive change and, instead, are relegated to a lower standard of living. This, in turn, causes society to miss out on the benefits of a more highly educated populace, and society as a whole suffers from this slight.

Government action guaranteeing student loans can raise the number of those receiving a higher education so that the optimal number of people (societal cost vs. societal benefit) are able to pursue a college degree. This will raise the standard of living for everyone and so should be a priority of both the federal and local governments.

Compounding the challenge of missing the external benefits of education due to the presence of externalities is the recent decline in the private incentive to the individual to attend college. The private incentive is falling due to the rising cost to the individual attending college. According to the National Center for Education Statistics (2013), the cost of tuition and room and board at US public universities has increased by $124 \%$ between 1981 and 2011, while that for private universities has increased by 129\%. During this same period of time, according to the Office of Financial Management, US per capita personal income has increased by $72 \%$. This suggests the private return to the US college graduates of a college education is falling. While this falling private incentive to the individual to attend college now confronts students and their parents, the return to a college education was higher than (and the authors believe, even today, remains higher) the return on an associate's degree or high school diploma during the high growth years of student loan volume analyzed in this paper.

\section{Government Action Affecting Risk And Return Of Student Loan Debt}

Implementation of the federal government support in the student loan market can be found in the Higher Education Act of 1965 and, in particular, the Federal Family Education Loan Program (FFELP). The specific structure created in the Federal Family Education Loan Program (FFELP) provided perverse incentives significantly impacting the student loan market that were eliminated in 2010.

The aptly named Student Aid and Fiscal Responsibility Act of 2009 (SAFRA) [H. R. 3221 2010] was added to the Reconciliation Act of 2010 which, in turn, was tacked onto the Patient Protection and Affordable Care Act that became law in March of 2010. The law was intended as a way to remove the federal government from the practice of subsidizing private student loans and, in doing so, make substantial cuts to the federal deficit. 
One of the driving forces behind this legislation occurred in 2007 when New York Attorney General Andrew Cuomo exposed corruption between financial firms lending to students and the colleges they attended. AG Cuomo found evidence that lenders had been buying off college loan officials to steer students in their direction when seeking money for school. According to the attorney general, as quoted in USA Today (2007), during the investigation they "found numerous arrangements that benefited schools and lenders at the expense of students". At the time, the federal government was subsidizing private student loans through the Federal Family Education Loan Program (FFELP) and, through that program, was funding over 80 percent of the student loans in this country, as noted by Brown (2010).

The government subsidy of the loans created a perverse incentive for private lenders to increase the risk in their loan portfolio. Under the FFELP, banks were able to game the system to the extent that the lenders actually profited more when students defaulted than when they were able to pay the loans back in full. Delinquent loans were turned over to a guaranty agency whose job it was to keep students caught up on the repayment schedule. For efforts made prior to default, guaranty agencies earned just one percent of the loan's outstanding balance. However, once the loan defaults and the agency regenerates it, the guarantor earns as much as $38.5 \%$ of the loan's balance, as noted by Brown (2010). Collection efforts were also much more profitable than efforts to avoid default, which gave guaranty agencies a major incentive to encourage delinquencies. These circumstances motivated lenders to avoid working with borrowers in order to encourage them to go into default; $60.5 \%$ of federal payments to FFELP in 2008 came from defaults as noted by Brown (2010).

Private lenders were, in effect, able to decouple the risks associated with student loans from their returns, leading to what Brown (2010) calls "an unwarranted form of welfare to a privileged financier class at the expense of struggling students". This situation arose due to the government subsidy, which made risky loans more valuable than low risk loans.

Under SAFRA, private lenders may no longer originate federal loans for students attending schools that are affiliated with the FFELP. This terminates the government subsidy of private loans. In addition, rates for Direct Loans under SAFRA are variable and are calculated as the effective annual rate on 91-day Treasury bills plus $2.5 \%$. These rates are typically adjusted every three to six months. Further, SAFRA sets a cap of $6.8 \%$ on these government loans. Private lenders have, to date, been unwilling to set any sort of cap on student loan rates. This is evidence that the banking industry believes they are justified in earning higher returns than the taxpayers while taking on less risk.

Private lenders typically have their variable student loan rates tied to either the federal funds rate or the LIBOR (plus a margin). This is also intended to protect the lenders' margin above their cost of borrowing. As discussed above, private lenders do not have a cap on interest rates at this time. Their margins are not limited to the $2.5 \%$ offered by the federal rates. Structuring the rates this way is intended to guarantee the government a return of $2.5 \%$ above what they pay for the short-term debt they issue, except during periods of very high interest rates (the yield on 91-day T-bills would have to exceed $4.3 \%$ for the cap to erode the loans' margin).

\section{Supply By Lenders Of Student Loans}

In several papers, Alonzi et al. $(1980,1983,2010,2011)$ have developed bank models to study the effects on bank lending decisions of deposit withdrawal risk, loan interest rate risk, and loan default risk. These models incorporate the interaction of time, bank-owner risk attitude, and uncertainties, including lending interest-rate uncertainty, deposit-flow uncertainty, and loan-repayment uncertainty. The analysis of these models provides consistent, similar closed form solutions for the bank lending decision with very intuitive explanations of bank lending rooted in the combined influence of these factors. However, none of the analyses of these models explicitly consider bank lending in the student loan market.

Returning to these solutions in light of the current student loan crisis and with a slight reinterpretation, they provide insight regarding the role of lender decision in the current crisis. Essentially, it seems reasonable to hold that the willingness of banks to make student loans was encouraged by a lessening degree of lender risk aversion during the frothy years leading up to the collapse of Lehman Brothers in September of 2008. This willingness to 
lend due to lessening risk aversion was reinforced by the reduced default risk faced by lenders due to changes in the laws (Bankruptcy Reform Act of 1978 and 2005 Bankruptcy Abuse Prevention and Consumer Protection Act), striking student loans from the list of items eligible for discharge in bankruptcy.

The models referred to above all consider the decisions of a perfectly competitive bank in lending markets. The bank owner is either one who exhibits constant absolute risk aversion, faces random variables that are uncorrelated, identically and normally distributed, and decides in an explicitly multi-period context or one who is risk neutral facing uncorrelated random variables making decisions in mono-period context.

Regardless of which particular model's result is considered, all the bank lending solutions reveal the effects on lending of the net interest return from lending, of discounting to account for the different timing of cash flows, and of the variability of the random variables. In a highly stylized form, the common closed form solution has the following basic structure: ${ }^{1}$

$L^{*}=\frac{\bar{l}_{L}-r_{D}}{\gamma b_{2} \sigma^{2}(l)}$

where,

$L^{*}$ is the optimal dollar amount of loans made taken here as student loans

$\overline{\mathrm{l}}$ is expected proportion of student loans repaying as agreed, $1 \geqq \overline{\mathrm{I}} \geqq 0$

$\sigma^{2}(1)$ is the variance of the proportion of student loans repaying as agreed

$\mathrm{r}_{\mathrm{L}}$ is the interest rate on student loans

$r_{D}$ is the interest rate the bank pays to borrow funds

$\gamma$ is the banker's coefficient of absolute risk aversion with $\gamma>0$

notably the greater $\gamma$, the more risk averse the bank lender

$b_{2}$ is discount factor using the riskless borrowing rate $r_{2}$ so $b_{2}=1+r_{2}$

This closed form solution shows the effects of uncertain loan repayment $\bar{l}_{L}$, bank borrowing cost $r_{D}$ and $b_{2 T}$, and risk attitude $\gamma$ on bank lending $L^{*}$. Specifically, direct inspection reveals that bank lending is directly related to the expected loan repayment interest rate on loans $\bar{l}_{L}$ while inversely related to bank borrowing costs $r_{D}$ and $b_{2 T}$ as well as the banker's degree of risk attitude $\gamma$ and the variance of the proportion of student loans repaying as agreed $\sigma^{2}(l)$.

The understanding of this closed form solution is enhanced by viewing it from another point of view which breaks the solution of $\mathrm{L}^{*}$ into the product of two parts - the incentive for one dollar of lending and a scaling factor:

$L^{*}=\left[\bar{l}_{\mathrm{L}}-\mathrm{r}_{\mathrm{D}}\right] /\left[\gamma \mathrm{b}_{2} \sigma^{2}(\mathrm{l})\right]=\left\{\left[\bar{l}_{\mathrm{L}}-\mathrm{r}_{\mathrm{D}}\right] / \mathrm{b}_{2}\right\}$ times $\left\{1 /\left[\gamma \sigma^{2}(1)\right]\right\}$

The first part, $\left[\bar{l}_{\mathrm{L}}-\mathrm{r}_{\mathrm{D}}\right] / \mathrm{b}_{2}$, is the present value of the expected interest rate spread to be earned on one dollar of lending and thus, it is the lender's incentive to engage in lending operations. The second part, $1 / \gamma \sigma^{2}(1)$, is the number of times one would want to replicate, and so, earn the first part. It is a scaling factor. This second part is determined by the interplay between the amount of risk represented by the variance of the loans repaying as agreed

${ }^{1}$ In particular, see Alonzi and Hutchinson (1983) Equation (4) on page 1046 and Alonzi (1980) Equation (9) on page 30. Note in the case of a risk neutral banker, the $\gamma$ does not enter the solution but the rising cost of deposit funding, due to rising bank size, does. Here in [1], the choice was made to indicate the affect of risk attitude rather than the rising cost of deposit funding as bank size increases. 
and the degree of the lender's risk aversion represented by gamma, $\gamma(\gamma$ is the Arrow-Pratt coefficient of absolute risk aversion which indicates risk aversion for any gamma greater than zero. The larger the gamma, the greater is the risk aversion; while the smaller, the less the risk aversion.)

Intuitively, the two parts of the rewritten solution for $\mathrm{L}^{*}$ reveal that the amount one would lend today depends upon the incentive for one dollar of lending (discounted expected interest rate spread), $\left[\bar{l}_{L}-r_{D}\right] / b_{2}$, amplified by the scaling factor, $1 / \gamma \sigma^{2}(1)$, which is the number of times one would want to earn that incentive.

Note that, ceteris paribus, the smaller the gamma, the less risk averse the lender, and so the larger the scaling factor which, in turn, leads to a larger amount of total lending $\mathrm{L}^{*}$. In the extreme case of gamma equal to zero, the lender would be risk neutral and $\mathrm{L}^{*}$ would be infinite (stated, more precisely, as gamma goes to zero, the scaling factor goes to infinity, and with it, $\mathrm{L}^{*}$ ). Essentially, if one is truly risk neutral, then the incentive provided by earning an expected positive spread $\bar{l}_{\mathrm{L}}>\mathrm{r}_{\mathrm{D}}$ is so strong that the lender wants to do as much $\mathrm{L}^{*}$ as possible.

Viewed in light of the student loan crisis with $\mathrm{L}^{*}$ representing student loans, two key insights emerge. First, during the frothy years preceding 2008, it is reasonable to think that bankers (or the managers retained by the bank owners $)^{2}$ might have become less risk averse. A reduction in risk aversion reduces $\gamma$ which, in turn, increases lending $L^{*}$ to students. This contributes to the explanation of the increased student loans by showing the increased willingness of lenders to make student loans as illustrated below.

The second insight is found by examining the effect of the variance of the proportion of student loans repaying as agreed, $\sigma^{2}(l)$. With the Bankruptcy Reform Act of 1978 removing government guaranteed student loans from the list of assets dischargeable in bankruptcy, reinforced by the 2005 Bankruptcy Abuse Prevention and Consumer Protection Act (Pub L. No. 109-8, 119 Stat. 23), removing even private (non-government guaranteed) student loans from the list of assets dischargeable in bankruptcy, the variance of the proportion of student loans repaying as agreed $\sigma^{2}(l)$ falls precipitously, if not to zero. Notably, as the denominator of L*'s closed form solution approaches zero, $\mathrm{L}^{*}$ soars. Essentially, the institutional changes made regarding the eligibility of student loans for discharge via bankruptcy contributed greatly to bank willingness to make student loans.

\section{CONCLUSION AND POLICY RECOMMENDATIONS}

The effects of the strands discussed above are combined and illustrated by the demand and supply framework presented in Figure 1. The demand for student loans has the usual negative slope. Notably, it is very large relative to supply due to students seizing the chance to move from one socio-economic level to another, which is supported by government subsidization of student borrowing. With the government setting an interest rate ceiling on student loan rates at Ceiling i below the equilibrium rate, the increase in bank sector lending leads to a dramatic increase in student loans from $\mathrm{Q}_{\mathrm{E}}$ to $\mathrm{Q}_{\mathrm{Z}}$ in Figure 1. In part, this increase in bank lending is due to less risk-averse (i.e., lower $\gamma$ in Equation [1] model) owners or their managers and, in part, due to less risk (i.e., lower $\sigma^{2}(l)$ resulting from student loans' non-dischargeability in bankruptcy). Notably, the falling $\sigma$ (the variability of loan repayment falls as loans are more likely to be repaid as agreed) raises bank lending for the prudent bank as well as for the profligate bank whose $\gamma$ falls as the profligate manager's low $\gamma$ replaces the bank owner's high $\gamma-$ the agency issue noted in footnote 2 . This increase in student loan dollars shifts the supply curve to the right, resulting in a big bulge in student loans $\mathrm{Q}_{\mathrm{E}}$ to $\mathrm{Q}_{\mathrm{Z}}$. That is, the student loan crisis arises as the confluence of the strands discussed above: 1) strong demand for loans by students seizing her/his dream of improving her/his socioeconomic standing with 2) the support of government subsidies, and 3) the increased appetite of banks to make student loans due to government reducing the risk associated with lending by guaranteeing student loans and disallowing the discharge of student loans in bankruptcy.

\footnotetext{
${ }^{2}$ This is the agency issue explored in Alonzi, Peter, Robert Irons, and Khalid Razaki (2010) and in Alonzi, Loreto Peter, Michael Hunstad, and Robert Irons (2011).
} 


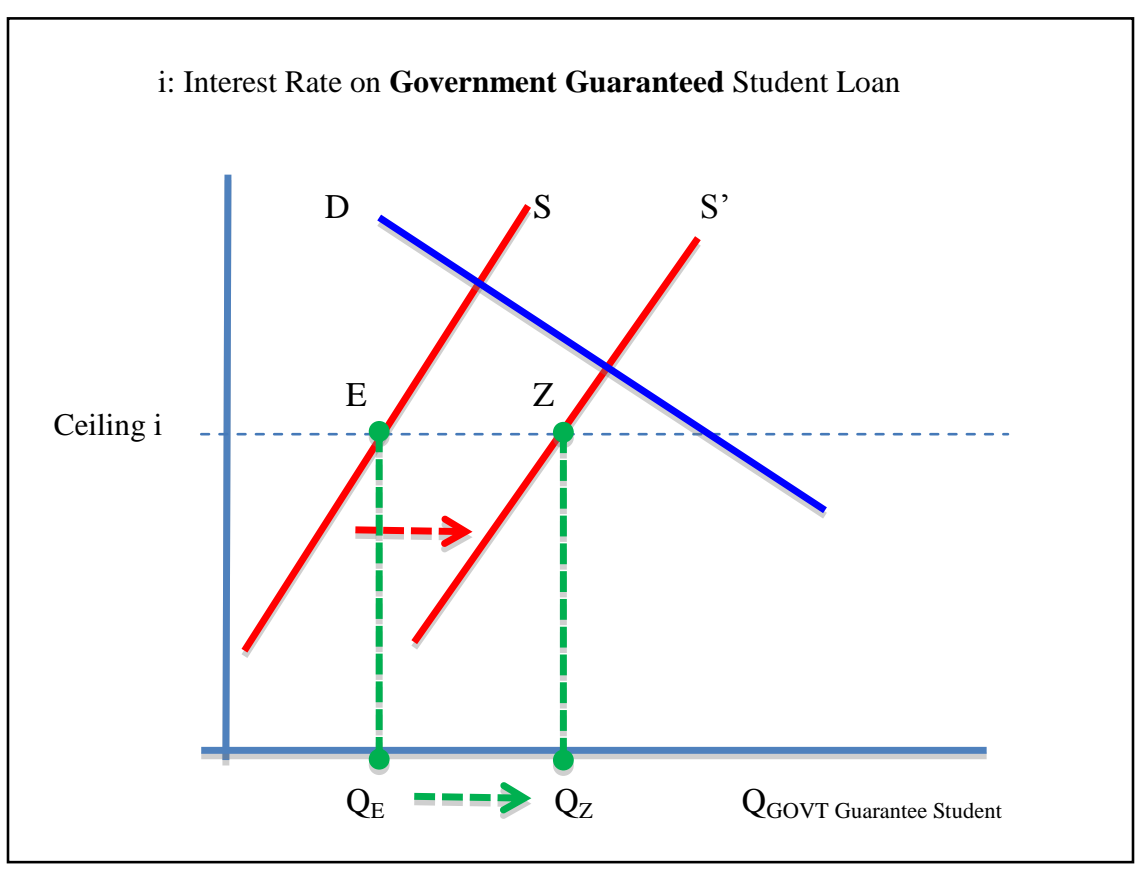

Figure 1: Interest Rate On Government Guaranteed Student Loan borrowers.

These results lead to policy recommendations in two broad areas: policies that apply to 1) lenders and 2)

For Lenders, given that student loans are no longer dischargeable in bankruptcy, the risk associated with student loans is reduced. This fact justifies requiring private lenders to treat student loans differently than other loans. To start with, there should be a cap on the rates private lenders can charge for student loans. Private lenders now have limited risk due to the changes in the bankruptcy laws and, therefore, a limited return is not out of line.

On the front end, lenders should be required to establish the borrower's creditworthiness and/or require cosigners on the loan or they should be held partially liable for contributing to the probability of default through poor due diligence. Similar to the legal concept of contributory negligence, this would motivate lenders to take the time and expense to investigate the borrower properly or allow student borrowers some recourse when they fail to do so.

On the back end, lenders should be required to offer options to potential defaulters that would permit them to deal with their difficult situations in order to get them back on track once the difficult circumstances are resolved. Deferring and forbearance, as offered by the government, should be offered and encouraged rather than pushing for default.

For students, student borrowers should have the ability to discharge student loans in bankruptcy court under extreme conditions. This would still offer reduced risk to lenders while not destroying student borrowers' lives.

\section{AUTHOR INFORMATION}

Loreto Peter Alonzi is Professor of Economics in Dominican University's Brennan School of Business. He holds a $\mathrm{Ph} . \mathrm{D}$. in Economics from the University of Iowa. Peter is a teacher, businessman, and scholar. His teaching excellence has been recognized at the University of Iowa, Bowling Green State University, and Dominican University. In business, he turned around a finance company (1980s) and led the Chicago Board of Trade's educational programs group (1990s). He served on the National Futures Association Education and Testing Advisory Committee and was the Illinois Economic Association's President (2008). He has published articles on teaching economics, futures markets, and banking. Email: Lpalonzi@dom.edu. (Contact Author) 
Robert Irons is an Associate Professor of Finance and Statistics in the Brennan School of Business at Dominican University. Dr. Irons received his Ph.D. from the Stuart School of Business at the Illinois Institute of Technology. He has published more than a dozen articles in such journals as the Journal of Investing and the Journal of Portfolio Management. Email: Rirons@dom.edu.

Kalid Razaki is a Professor of Accounting in the Brennan School of Business at Dominican University which he joined after 28 years on the accounting faculty at Illinois State University where he rose to Full Professor of Accounting. He obtained a Ph.D. in Accounting from the University of Illinois at Urbana-Champaign. He has published over 40 articles in various academic and practitioner journals, including the International Journal of Accounting, Decision Sciences, and the Internal Auditor. Email: Krazaki@ dom.edu.

\section{REFERENCES}

1. Alonzi, Loreto Peter. (1980). Policy Implication of Bank Repurchase Agreement. The Journal of Economics, VI, 29-32.

2. Alonzi, Loreto P., and Hutchinson, Peter. (1983). Risk Aversion's Impact on Bank Mortgage Lending: Evidence from the USA. Rivista Internazaionale di Scienze Economiche e Commerciali, OttobreNovembre, Anno XXX. n. 10-11, 1039-1056.

3. Alonzi, Peter, Irons, Robert, and Razaki, Khalid. (2010). Asymmetric Information, Moral Hazard, and Agency Problems in Bank Lending. Financial Decisions, Winter, 1-21.

4. Alonzi, Loreto Peter, Hunstad, Michael, and Irons, Robert. (2011). Gresham's Law Revamped: Lending for Short-Term Profits Drives Out Prudent Long-Term Lending. Financial Decisions, Winter, 1-29.

5. American Student Assistance. (2013). Student Loan Debt Statistics. Retrieved from: http://www.asa.org/resources/stats/.

6. Blumenstiyk, G. (2012, February 23). Senate Committee's Report Focuses on For-Profit Colleges' Share of Military Education Benefits. The Chronicle of Higher Education. Retrieved from http://chronicle.com/article/US-Senate-Panel-Examines/130909/.

7. Brown, E. (2010). Student Loans: The Government is Now Officially in the Banking Business. Huffington Post. Retrieved at www.huffingtonpost.com/ellen-brown/student-loans-the-governm b 520318.html.

8. Brown, M., Haughwout, A., Lee, D., Mabutas, M., and Klaauw, W. (2012, May 5). Grading Student Loans. Liberty Street Economics. Retrieved from http://libertystreeteconomics.newyorkfed.org/2012/03/gradingstudent-loans.htmll.

9. Carnevale, A., Rose, S., and Cheah, B. (2010). The College Payoff: Education, Occupation, Lifetime Earnings. Center on Education and the Workforce, Georgetown University. Retrieved from http://www9.georgetown.edu/grad/gppi/hpi/cew/pdfs/collegepayoff-complete.pdf.

10. Customer Financial Protection Bureau. (2012, July 20). Private Student Loans. Report to the Senate Committee on Banking, Housing, and Urban Affairs, the Senate Committee on Health, Education, Labor, and Pensions, the House of Representatives Committee on Financial Services, and the House of Representatives Committee on Education and the Workforce. Retrieved from http://www.consumerfinance.gov/reports/private-student-loans-report/.

11. Dai, E. (2013). Student Loan Delinquencies Surge. Federal Reserve Bank of St. Louis. Retrieved from: http://www.stlouisfed.org/publications/itv/articles/?id=2438.

12. Eaton, C. (2011, September 22). 8 For-Profit Colleges Collect more than \$1-Billion in Veterans' Education Benefits. The Chronicle of Higher Education. Retrieved from http://chronicle.com/article/8-For-ProfitColleges-Collect/129124/.

13. Federal Reserve Bank of New York. (2012, May). Quarterly Report on Household Debt and Credit. Research and Statistics Group in Microeconomic Studies. Retrieved from http://www.newyorkfed.org/research/national_economy/householdcredit/DistrictReport_Q42011.pdf.

14. Glater, J. (2008). That Student Loan, So Hard to Shake. The New York Times. Retrieved from www.nytimes.com/2008/08/24/business/24loans.html? r=3\&em\&oref=slogin\&.

15. Howard, W. S. (2011). The Student Loan Crisis and the Race to Princeton Law School. Journal of Law, Economics \& Policy.7 (3), 485-511.

16. Jacobs, E. (2010). Interest Rates are Down, Time to Get a Private Student Loan? Ezine Articles. Retrieved from ezinearticles.com/?Interest-Rates-Are-Down,-Time-to-Get-a-Private-Student-Loan?\&id=4270855. 
17. Lederman, D. (2009). The Student Loan Scam. Inside Higher Education. Retrieved from www.insidehighered.com/news/2009/05/05/collinge.

18. Lederman, D. (2010). Student Loan Bill Scorecard. Inside Higher Education. Retrieved at www.insidehighered.com/news/2010/03/24/scorecard.

19. Leonard, A. (2012, June 26). Salon. Retrieved from http://www.salon.com/2012/06/26/a_deal_on_student_debt/.

20. Martin, A., and Lehren, A. (2012, May 12). A Generation Hobbled by the Soaring Cost of College. The New York Times. Retrieved from http://www.nytimes.com/2012/05/13/business/student-loans-weighingdown-a-generation-with-heavy-debt.html?pagewanted=all\&_r=0.

21. National Center for Education Statistics. (2013). Retrieved from http://www.nces.ed.gov.

22. Office of Financial Management. Retrieved from www.ofm.wa.gov.

23. Pew Foundation. (2014). "The Rising Cost of Not Going to College." Pew Research Social \& Demographic Trends. Retrieved from http://www.pewsocialtrends.org/2014/02/11/the-rising-cost-of-not-going-tocollege/.

24. Pilon, M. (2010). The \$555,000 Student-Loan Burden. The Wall Street Journal. Retrieved from online.wsj.com/news/articles/SB10001424052748703389004575033063806327030.

25. Razaki, K., Koprowski, W., and Lindberg, D. (Summer 2014) (forthcoming).The Student Loan Crisis: Background, Motivations of Participants, and Regulatory Issues. Journal of Business and Behavioral Sciences.

26. USA Today. (2007, April) Sallie Mae pays $\$ 2 \mathrm{M}$ in student-loan scandal settlement. retrieved from http://usatoday30.usatoday.com/money/industries/banking/2007-04-11-sallie-mae-settlement_N.htm.

27. Stone, C., Van Horn, C., and Zukin, C. (2012, May). Chasing the American Dream: Recent College Graduates and the Great Recession. John J. Heldrich Center for Workforce Development at the Edward J. Bloustein School of Planning and Public Policy, New Brunswick . Retrieved from http://www.heldrich.rutgers.edu/sites/default/files/content/Chasing_American_Dream_Report.pdf.

28. U.S. Department of Education [DOE]. (2011 A). "Strategic Plan FY 2012-2016: Funding America's Future one Student at a Time." Federal Student Aid. Retrieved from: http://www2.ed.gov/about/offices/list/fsa/fiveyearplan.pdf.

29. U.S. Department of Education [DOE]. (2011 B). "Your Federal Student Loans: Learn Basics and Manage Your Debt." Federal Student Aid. Retrieved from: https://studentaid.ed.gov/sites/default/files/your-federalstudent-loans 1.pdf. 